\title{
The Impact of Self Efficacy on the Foot Care Behavior of Type 2 Diabetes Mellitus Patients in Indonesia
}

\author{
Nuh Huda ${ }^{1}$, Tintin Sukartini ${ }^{1}$ and Nadya Wahyu Pratiwi ${ }^{2}$ \\ ${ }^{1}$ Faculty of Nursing, Universitas Airlangga, Surabaya, East Java, Indonesia \\ ${ }^{2}$ Sekolah Tinggi Ilmu Kesehatan Hang Tuah Surabaya, East Java, Indonesia
}

\begin{abstract}
Introduction: Diabetes mellitus (DM) often causes complications, one of which is diabetic foot ulcers (DFUs). One of the factors involved in preventing diabetic foot injuries is performing foot care behavior. To improve patient behavior in terms of performing foot care is to improve self-efficacy. The purpose of this study was to determine the effect of the self-efficacy of diabetes patients on foot care behavior.
\end{abstract}

Methods: This study used a descriptive correlational design to reveal the correlative relationships between the variables with a sample of 106 respondents using probability sampling in the form of cluster random sampling. The data was collected using questionnaires, the foot care confidence scale (FCCS), and the foot care behavior scale for diabetes (FCBS for Diabetes). The independent variable of this study was the self-efficacy of DM sufferers and the dependent variable of this study was the behavior of foot care. The data analysis used the Spearman Rho correlation test $(\alpha=0.05)$.

Results: Spearman Rho correlation test showed there to be a relationship between the self-efficacy of people with diabetes mellitus and foot care behavior $\mathrm{p}$ value = $0.001(\mathrm{p}<0.05), \mathrm{r}=-0.542$.

Conclusion: The implication of this study is that a high self-efficacy in people with diabetes mellitus will improve the behavior related to foot care, thereby reducing the risk of behaviors that damage the feet.

\section{ARTICLE HISTORY}

Received: Dec 18, 2019

Accepted: Jan 13, 2020

\section{KEYWORDS}

diabetes mellitus; foot care behavior; self-efficacy

\section{CONTACT}

Nuh Huda

$\triangle$ nuh.huda-2018@fkp.ac.id

$\equiv$ Faculty of Nursing,

Universitas Airlangga,

Surabaya, East Java, Indonesia

Cite this as: Huda, N., Sukartini, T., \& Pratiwi, N, W. (2019). The Impact of Self Efficacy on the Foot Care Behavior of Type 2 Diabetes Mellitus Patients in Indonesia. Jurnal Ners, 14(2), 181-186.

doi:http://dx.doi.org/10.20473/jn.v14i2.16741

\section{INTRODUCTION}

DM has complications that have a great chance of causing death. DFU is one of the most common complications of DM which is the main cause of many hospitalizations due to a lack of foot care behavior. This subsequently leads to the amputation of the lower extremities (Pourhaji et al., 2016). Foot care behavior is often neglected, especially by adults and the elderly. Foot care education is one of the best tools available to increase the awareness of people with diabetes mellitus on the matter of proper foot care behavior (Zaman, Shah and Hussein, 2018). Some of the most common cases of DM include the problem of DFU every year. The number of people suffering from DM is increasing due to limitations in terms of self foot care behavior. One of the limitations is that the health workers have counseled them about diabetes mellitus but without any follow up, it is uncertain whether the DM sufferers have understood and are convinced of what is being delivered by the health workers. Many DM sufferers seem to have not cut their nails straight, the skin of DM sufferers' feet looks dry and some of the sufferers are not sure that they can take care of the feet because of the lack of a support system from their family and the environment around them. There needs to be a support system when a patient forgets. It is expected that they will have someone to remind and convince them that they are able to take preventive behavior steps in relation to their illness. If proper foot care is not carried out, then certain chronic complications of diabetes mellitus, especially diabetic foot ulcers, can occur in people with DM. The existence of these limitations is influenced by self-efficacy. This is one's belief in their ability to perform a behavior that is expected to change one's health behavior (Sharoni et al., 2018). 
The WHO (World Health Organization) estimates that 108 million people live with DM. This number increased in 2015 to 415 million people, while the estimates for 2017 - 2045 according to the IDF showed a total of 7.5-9.5 billion world population. The prevalence of diabetes is 425 - 628.6 million people around the world. According to the WHO data in 2017, the prevalence of DM sufferers with neuropathic disorders reached $50 \%$ and those with leg injuries reached 15 - 25\% (International Diabetes Federation (IDF), 2017). The results of research conducted in Arabic states that $70 \%$ of lower extremity amputations are DM sufferers with leg injuries (Al-Hariri et al., 2017). Indonesia ranks 7th in the world with the highest number of DM sufferers and the estimates reach 6.7 - 11.1 million sufferers. The results of the 2018 Riskesdas survey showed that the prevalence of DM in the Indonesian population aged $>15$ years old has increased to $8.5 \%$. East Java ranks 5 th in the number of DM sufferers in Indonesia at $7.6 \%$ (Depkes RI, 2018). DM patient data from the Surabaya district/city Health Office in 2018 for the working area of the Puskesmas in Wonocolo District, namely Siwalankerto Puskesmas, showed that there were 1,140 DM patients and for Sidosermo Puskesmas, there were 2,790 DM patients (Dinas Kesehatan Kota Surabaya, 2018).

Behavior is very much involved in preventing the complications of DM. Behavior is a complex process and it is influenced by several factors such as knowledge, self-confidence, attitudes, skills, motivation and social support. This is needed to make improvements in self-care behavior. One of the determining factors in achieving a behavior is selfefficacy (self-confidence). Self-efficacy is a person's self-confidence in their ability to perform a behavior that needs to be done to achieve goals, tasks, and challenges set. Self-efficacy describes the interaction between the behavioral, personal, and environmental factors in the context of health and chronic diseases. This is also a belief that affects people with diabetes mellitus concerning whether they are able to perform health behaviors. People with high self-efficacy believe that they are able to do difficult tasks well, as something that must be mastered is not something that should be avoided. It can be estimated that the DFU risk will decrease with the increase in foot care behavior (Hamedan, Hamedan and Torki, 2012). The purpose of this study was to determine the impact of diabetes self-efficacy on foot care behavior in Surabaya.

\section{MATERIALS AND METHODS}

This study used a descriptive correlational design that reveals the correlative relationship between variables, which is related to getting to know the relationship between the self-efficacy of diabetics and foot care behavior. This research was conducted in the working area of Wonocolo District Health Center (UPTD Siwalankerto Health Center and Sidosermo Health Center) in May - July 2019. The population consisted of 3,930 respondents. The sampling technique in this study was probability sampling where the cluster random sampling approach was done twice, first based on the number of villages and second based on age range. A sample of 106 respondents was finally obtained. The instrument used in this study was the Foot Care Confidence Scale (FCCS) questionnaire (Sloan, 2002) used to measure the self-efficacy of diabetics consisting of 12 questions. The interpretation of the results was that high scores indicate high self-efficacy and low scores indicate low self-efficacy. After testing the reliability and validity by calculating the coefficient between the item scores and total scores in the range of 0.30 and 0.70 , Cronbach's alpha was 0.90 for the 12 question items. They showed strong content validity and construction when performing foot care behavior based on the confidence scale (Pourhaji et al., 2016). The FCBS for Diabetes (Foot Care Behavior Scale for Diabetes) questionnaire was used to measure foot care behavior consisting of 17 questions evaluating two behaviors, namely prevention and risk behavior with the interpretation of the high score results indicating the risk of high destructive behavior and with a low score indicating that the damage risk was low (García-inzunza et al., 2015).

The data collection was carried out using a questionnaire addressed to all Type 2 DM patients in the community. The previous respondents received an explanation of self-efficacy and foot care behavior, so it was hoped that the questionnaire would be filled in correctly. The authors found 126 people willing to become respondents, although 20 people resigned for the reason of not being able to do foot care because of their age, weakness and moving out of town. We got 106 respondents in total. The inclusion criteria were as follows: DM type 2 sufferers, control done at the Puskesmas and aged 15-60 years. The exclusion criterion were that the patient dropped out before the end of the study, there were complications regarding their leg injury, mental disability and decreased health/awareness. The analytical test used was the Spearman Rho Correlation Test $(\alpha=0.05)$ with SPSS $\mathrm{v}-23$. A statement of medical research ethics was issued by the Health Research Ethics Commission (KEPK) of STIKes Hang Tuah Surabaya in accordance with number: PE/38/V/2019/KEPK/SHT.

\section{RESULTS}

Based on the table 1 , the characteristics of the respondents in this study included age, sex, last education stage, occupation, duration of diabetes mellitus, understanding every month, and had received counseling. it can be explained that the characteristics of the respondents showed that most were aged 51-60 years (52.8\%) and most were female sex $(65.1 \%)$. The majority were also educated at the high school/equivalent level (34.9\%), in private employment $(54.7 \%)$, had suffered from diabetes mellitus $2-3$ years $(40.6 \%)$, had a monthly income of 
Table 1. Characteristic of Respondents $(n=106)$

\begin{tabular}{|c|c|c|}
\hline Characteristics of the respondents & $\mathbf{n}$ & $\%$ \\
\hline \multicolumn{3}{|l|}{ Age } \\
\hline $15-23$ years old & 1 & 0.94 \\
\hline 24-32 years old & 4 & 3.77 \\
\hline 33-41 years old & 8 & 7.55 \\
\hline $42-50$ years old & 37 & 34.91 \\
\hline 51-60 years old & 56 & 52.83 \\
\hline \multicolumn{3}{|l|}{ Sex } \\
\hline Male & 37 & 34.91 \\
\hline Female & 69 & 65.09 \\
\hline \multicolumn{3}{|l|}{ Educations } \\
\hline Primary school & 11 & 10.38 \\
\hline Junior high school & 35 & 33.02 \\
\hline Senior high school & 37 & 34.91 \\
\hline Bachelor & 23 & 21.70 \\
\hline \multicolumn{3}{|l|}{ Work } \\
\hline Not working & 2 & 1.89 \\
\hline Private & 58 & 54.72 \\
\hline Employee & 20 & 18.87 \\
\hline Others & 26 & 24.53 \\
\hline \multicolumn{3}{|l|}{ Duration Suffering from DM } \\
\hline$<1$ years & 1 & 0.94 \\
\hline$>1-2$ years & 30 & 28.30 \\
\hline 2-3 years & 43 & 40.57 \\
\hline 4-5 years & 24 & 22.64 \\
\hline$>6$ years & 8 & 7.55 \\
\hline \multicolumn{3}{|l|}{ Income } \\
\hline$<1$ million (IDR) & 7 & 6.60 \\
\hline >1-2 million (IDR) & 22 & 20.75 \\
\hline 2-3 million (IDR) & 30 & 28.30 \\
\hline 3-4 million (IDR) & 30 & 28.30 \\
\hline 4-5 million (IDR) & 17 & 16.04 \\
\hline \multicolumn{3}{|l|}{ Counselling } \\
\hline Yes & 42 & 39.62 \\
\hline No & 64 & 60.38 \\
\hline
\end{tabular}

2-4 million IDR (56.6\%), and had never received counseling (60.4\%) regarding foot care behavior.

Based on Table 2, it shows that out of 106 respondents, people with diabetes mellitus with low self-efficacy were as many as 21 respondents (19.8\%). Those with high self-efficacy were as many as 85 respondents $(80.2 \%)$. DM sufferers with low self-efficacy were as many as 21 respondents out of the total of 106 respondents. The results of the questionnaire showed that the respondents mostly had low self-efficacy because they were not sure after washing the feet if they had to dry the feet between the toes. Having wet feet can cause a fungus, resulting in damage to the cells of the feet. The respondents were not sure that they should cut their nails straight. They preferred to follow the shape of the nails if they were done often. This can cause lesions and infections that we usually call 'slants'. This shows that out of the 106 respondents, there are people with diabetes mellitus who have a low risk of destructive behavior (as many as 83 respondents; 78.3\%) and those who have a high risk of destructive behavior (as many as 23 respondents; $21.7 \%$ ). The DM sufferers who have a low risk of destructive behavior totaled 83 respondents.

\section{DISCUSSION}

The respondents were less confident when examining the inside of their shoes before using it. This can harm their feet as there may be foreign objects that can cause lesions on the feet. Patients who have low selfefficacy tend to doubt their abilities and they encounter difficult problems because they usually assume that any problem is a threat (Bahador et al., 2017). Someone with low self-efficacy tends to be slow at getting their self-efficacy back when it causes them to fail to deal with problems (D'Souza et al., 2017). Someone with low self-efficacy does not think of the best way to deal with the tasks that must be done, especially foot care in order to prevent complications. They will be disturbed by doubts about their abilities and they will easily give up when faced with difficulties doing the task. Chronic illness can be a trigger for low self-efficacy because the longer the illness is suffered from, the more problems will be faced by the sufferers. Someone who has low self-efficacy is usually busy thinking about deficiencies in themselves. They quickly give up when faced with problems. There were 21 respondents with low self-efficacy, there were 14 respondents also with a high risk of destructive behavior and 7 have a low risk of damage. This will be much influenced by 
Table 1. Impact of Self-Efficacy on Diabetic Foot Care Behaviors $(n=106)$

\begin{tabular}{|c|c|c|c|c|}
\hline \multirow{2}{*}{\multicolumn{2}{|c|}{ Self-efficacy of DM patients }} & \multicolumn{2}{|c|}{$\begin{array}{l}\text { Foot care behavior } \\
\end{array}$} & \multirow[b]{2}{*}{ Tota } \\
\hline & & $\begin{array}{c}\text { Low risk destructive } \\
\text { behaviors }\end{array}$ & $\begin{array}{c}\text { High risk destructive } \\
\text { behavior }\end{array}$ & \\
\hline \multirow{2}{*}{ Low Self-efficacy } & $\mathrm{n}$ & 7 & 14 & 21 \\
\hline & $\%$ & 6.6 & 13.2 & 19.8 \\
\hline \multirow{2}{*}{ High Self-efficacy } & $\mathrm{n}$ & 76 & 9 & 85 \\
\hline & $\%$ & 71.6 & 8.4 & 85.8 \\
\hline \multirow{2}{*}{ Total } & $\mathrm{n}$ & 91 & 15 & 106 \\
\hline & $\%$ & 78.3 & 21.7 & 100 \\
\hline \multicolumn{5}{|c|}{ Spearman's rho test; $0,001(\rho<0.05)$ Correlation coefficient; $-0.542^{*}$} \\
\hline
\end{tabular}

the behavior that is often done in their daily lives. They can gain experience because of discussing things with fellow sufferers or seeing related topics through mass media. The daily behavior that has been done will affect the behavior when someone is in a state of experiencing an illness.

The results of the questionnaires showed that some of the respondents chose behavior used for prevention, namely the frequent checking of the feet, often washing their feet and drying them using a small towel, often checking the inside of their shoes before using them and measuring their foot size first before buying new shoes. Good behavior in terms of foot care can be done in several ways: 1) clean, dry and gentle foot care, 2) skin care, 3) nail care and 4) using the right shoes (Heitzman, 2010). A low risk of destructive behavior can occur when the respondent already knows and can perform good foot care behavior in the way that is available. Based on these results, the DM sufferers said that they already knew how to take care of their feet and some of them had applied this well. For the results of filling in the FCBS for diabetes questionnaire, many of the respondents answered question no. 2 about how often they had wash their feet in the past week; some of the respondents answered $2 \mathrm{x}$ /day while in reality, other respondents washed feet $5-10 x /$ day. This is done by the respondents when they feel that their feet are dirty and dry. They do so to moisturize their feet. They prefer washing their feet instead of using foot lotion, which according to them means that their feet will feel more comfortable, not dry, fresh, and clean. After washing their feet, the respondents did not forget to dry them with a small towel. The most frequent statement within the category of risky behavior done by the respondents was walking barefoot in the room. According to them, if they are in their house, then they do not have to use footwear because the house is clean and has a ceramic floor. Thus there is no need to use footwear inside the house, except when performing prayer at the time of ablution when they usually use footwear from the bathroom through to the place of prayer in the house (Maslakpak, 2017).

Correlation coefficient(r) shows the result of -,542 * which means that there is a significant relationship between the two variables. This shows that there is a negative correlation, so the higher the self-efficacy, the lower the risk of destructive behavior and vice versa. The lower the self-efficacy, the more that the risk of destructive behavior will be high. The negative sign indicates that the direction of the correlation is the opposite, which means that the higher the selfefficacy of people with diabetes mellitus, the lower the risk of destructive foot care behavior. Self-efficacy is known as one of the resources used by someone when carrying out their personal tasks. Self-efficacy is not related to the skills possessed by individuals but it instead relates to individual beliefs in the things done (Brown, Malouff and Schutte, 2013). The results of this study are supported by the research which has revealed that patients who have higher self-efficacy will have good self-care behavior. Other studies support this research (Sharoni et al., 2018). These studies have revealed the existence of a self-efficacy program that can improve the self-care foot behavior in relation to the program delivered. Research by (Pourhaji et al., 2016) concludes that the belief in performing foot care by improving the physical selfconcept can help to improve the foot care behavior among people with diabetes mellitus. According to researchers, the existence of good self-care behavior can reduce the risk of destructive behavior. The selfefficacy of diabetics in foot care is needed to maximize the foot care behavior to prevent diabetes mellitus complications. Patients are expected to be able to apply self-efficacy optimally through foot care behavior. Perceived self-efficacy can also have an impact on the efforts made when handling a task or problem, especially health problems. Health education must continue to be done to improve sufferers' self-efficacy of foot care behavior. The characteristics of individuals who have high selfefficacy include where they feel able to deal effectively with the events and situations faced, that they persevere in completing their existing tasks, that they are always confident in their abilities and that they view difficult situations as challenges rather than as threats. This is in addition to designing their own goals, increasing their strong commitment to themselves increasing the strong effort to do everything, increasing the effort needed to deal with failure, thinking to strategize in the face of adversity, quickly restoring the sense of being able to fail, and being able to deal with stressors.

Out of the sample, 23 DM sufferers have a high risk of destructive behavior. This can be interpreted as poor foot care behavior. The respondents stated that 
they sometimes walked barefoot outside of the room, that they often wore shoes without socks and that they sometimes use tape on the feet to remove calluses. According to the research, it revealed that the low foot care behavior may occur when people with diabetes mellitus have difficulty checking feet; help from others may be needed (Cousart and Handley, 2017). The results of the respondents ignoring doing their routine foot care for several reasons is that they often forget, are lazy, do it in a manner that is not in accordance with what is usually done, and they feel uncomfortable in the way that it is given. One of these behaviors is where they rarely cut their nails straight to avoid lesions; some of them prefer to cut their nails according to their shape.

Meanwhile, 85 other respondents had high selfefficacy. The respondents said that they were confident in terms of protecting their feet, examining their feet every day to check for cuts, scratches, blisters, redness, or dry feet, and choosing good and suitable shoes without relying on having a suitable feeling. Patients who have high self-efficacy usually tend to choose being directly involved in solving problems even though the problems faced are difficult. This is because people with a high selfefficacy look more at the problem rather than at the threat that must be avoided (D'Souza et al., 2017). Someone with high self-efficacy can overcome their problems effectively and they will try hard to deal with all of the difficulties encountered. They will persist in carrying out a task when they already have the prerequisite skills in accordance with the existing rules.

Previous research by D'Souza (2017) on foot care behavior shows that positive behavior correlates with a positive attitude and awareness of diabetes management. Patients are able to behave better in the prevention of foot injuries through the use of footwear by $47.14 \%$, using foot moisturizer by $44.29 \%$, walking without a pedestal by $53.57 \%$, inspecting their shoes before use by $49.29 \%$ and cutting the nails by $60.71 \%$. This study recommends an increase in self-efficacy that involves families in the prevention of diabetic foot injuries (D'Souza et al., 2017). One of the determining factors in achieving behavior is self-efficacy. Another study stated that self-efficacy improvement programs are able to improve foot-care behavior and they recommend that the theory of self-efficacy be included in DM education programs to improve foot-care behavior (Sharoni et al., 2018). Behavior arises because of the intention to behave. Intentions can be predicted from attitudes, subjective norms and the perception of selfcontrol The greater the intention to take preventative measures, the greater the chance of improving the health behavior (Nursalam, 2015). Self-efficacy is the human belief in their ability to perform an expected behavior, in particular control of the self-function to achieve the expected results. Self-efficacy is different from the aspirations or ideals that describe something that can be achieved, as it is more due to the belief in one's abilities. Self-efficacy is a construct based on social cognitive theory. Human actions have a reciprocal relationship where there are individuals, the environment and behavior (Chin, Huang and Hsu, 2012). Most respondents have the assumption that with positive thinking patterns and self-confidence in their ability to deal with every problem, there is the existence of motivation and support among the family members which can increase their confidence.

Self-efficacy is an individual's belief in their ability to exercise control over various self-functions and events in their environment. The ability of the individuals to improve their motivation, cognitive resources and actions is needed to meet the demands faced. Efficacy refers to the belief that an individual is able to estimate his or her ability to carry out tasks in order to achieve the expected results. Efficacy always develops continuously in someone who is in line with the ability and number of experiences or events that they experience (Bandura, 1997).

\section{CONCLUSION}

The higher the self-efficacy of people with diabetes mellitus, the better their foot care behavior. They will have a lower risk of potentially damaging behavior related to foot care.

\section{REFERENCES}

Al-Hariri, M. T. et al. (2017) 'Descriptive study on the knowledge, attitudes and practices regarding the diabetic foot', Journal of Taibah University Medical Sciences, 12(6), pp. 492-496. doi: 10.1016/j.jtumed.2017.02.001.

Bahador, R. S. et al. (2017) 'The impact of three-month training programme on foot care and self-efficacy of patients with diabetic foot ulcers', Journal of Clinical and Diagnostic Research, 11(7), pp. IC01IC04. doi: 10.7860/JCDR/2017/29025.10261.

Bandura (1997) 'self Efficacy: Toward a Unififying Theori of Behavioral Change Psycological Review'.

Brown, L. J., Malouff, J. M. and Schutte, N. S. (2013) 'Self-Efficacy Theory', pp. 13-38.

Chin, Y., Huang, T. and Hsu, B. R. (2012) 'Impact of action cues, self-efficacy and perceived barriers on daily foot exam practice in type 2 diabetes mellitus patients with peripheral neuropathy', (259), pp. 61-68. doi: 10.1111/j.13652702.2012.04291.x.

Cousart, T. H. and Handley, M. (2017) 'Implementing Diabetic Foot Care in the Primary Care Setting', Journal for Nurse Practitioners. Elsevier, 13(3), pp. e129-e132. doi: 10.1016/j.nurpra.2016.11.009.

D'Souza, M. S. et al. (2017) 'Self-efficacy and self-care behaviours among adults with type 2 diabetes', Applied Nursing Research. Elsevier Inc., 36, pp. 2532. doi: 10.1016/j.apnr.2017.05.004.

Depkes RI and Depkes (2018) Riskesdas 2018.

Dinas Kesehatan Kota Surabaya (2018) Profil Kesehatan Kota Surabaya 2017. Available at: http://www.depkes.go.id/resources/download/ profil/PROFIL_KAB_KOTA_2016/3578_Jatim_Kot 
a_Surabaya_2016.pdf.

García-inzunza, J. A. et al. (2015) 'Validity of the Mexican version of the combined Foot Care Confidence / Foot-Care Behavior scale for diabetes', 38(1), pp. 35-41.

Hamedan, Maryam Shabani, Hamedan, Marzieh Shabani and Torki, Z. (2012) 'Relationship between Foot-Care Self-Efficacy Beliefs and Self Care Behaviors in Diabetic Patients in Iran (2011)', Journal of Diabetes \& Metabolism, 3(9). doi: 10.4172/2155-6156.1000220.

Heitzman, J. (2010) 'Foot Care for Patients With Diabetes', Topics in Geriatric Rehabilitation, 26(3), pp. 250-263.

International Diabetes Federation (IDF) (2017) IDF Diabetes Atlas 8th edition, Idf.Org. doi: 10.1289/image.ehp.v119.i03.

Maslakpak (2017) 'Preventing and managing diabetic foot ulcers: application of Orem's self-care model', International Journal of Diabetes in Developing Countries. International Journal of Diabetes in Developing Countries, 38(2), pp. 165-172. doi: 10.1007/s13410-017-0570-5.

Nursalam (2015) Motodologi Penelitian Ilmu
Keperawatan. edisi 4. Jakarta: Salemba Medika.

Pourhaji, F. et al. (2016) 'Foot-Care Self-efficacy Beliefs, Physical Self-Concept and Actual FootCare Behavior in People with Diabetes Mellitus', International Journal of Musculoskeletal Pain Prevention, 1(3), pp. 101-107.

Sharoni, S. K. A. et al. (2018) 'The effects of selfefficacy enhancing program on foot self-care behaviour of older adults with diabetes: A randomised controlled trial in elderly care facility, Peninsular Malaysia', PLoS ONE, 13(3), pp. 1-23. doi: 10.1371/journal.pone.0192417.

Sloan, H. L. (2002) 'Developing and testing of the foot care confidence scale', Journal of Nursing Measurement, 10(3), pp. 207-218. doi: 10.1891/jnum.10.3.207.52564.

Suharsono, Y. and Istiqomah (2014) 'Validitas Dan Reliabilitas Skala Self-Efficacy', Jurnal Ilmiah Psikologi Terapan, 02(01), pp. 144-151.

Zaman, K., Shah, M. and Hussein (2018) 'Knowledge And Practice Of Foot Care Among Diabetic Elderly In UKM Medical Centre (UKMMC)', The Malaysian Journal of Nursing, 9(3), pp. 6-12. 